\title{
The Effect of Learning Strategies and Linguistic Intelligence on the Results of English Texts Reading Comprehension for High School Students in Medan
}

\author{
Tiarmayanti Novita Sonia ${ }^{1}$, Andrew Ryan Hasudungan Siallagan ${ }^{2}$, \\ Abdul Muin Sibuea ${ }^{3}$, Sugiharto ${ }^{4}$ *
}

\author{
${ }^{1}$ Teknologi Pendidikan, Universitas Negeri Medan, Sumatera Utara, Indonesia \\ ${ }^{2}$ Teknologi Pendidikan, Universitas Negeri Medan, Sumatera Utara, Indonesia \\ ${ }^{3}$ Teknologi Pendidikan, Universitas Negeri Medan, Sumatera Utara, Indonesia \\ ${ }^{4}$ Teknologi Pendidikan, Universitas Negeri Medan, Sumatera Utara, Indonesia \\ Corresponding author.Email : tiarmayanti83@gmail.com, multitalent86@gmail.com,sibuea.muin@gmail.com, \\ sugiharto@gmail.com
}

\begin{abstract}
The objectives of this research are: (1) the difference of results of students' English text comprehension who are taught with the Collaborative Strategic Reading (CSR) strategies and student taught by using the Directed, Reading, Thinking, Activity (DRTA) strategy (2) the difference of results the students who have high linguistic intelligence is better than students who have low linguistic intelligence (3) the interaction between learning strategies and linguistic intelligence in influencing students' learning outcomes of understanding English texts. This study is a quasiexperimental research. The population in this study all students of class XI MIPA SMA Negeri 2 Medan and XI MIPA SMA Negeri 5 Medan. The research instrument is an objective test of valid and reliable learning outcomes of students' English text comprehension, and a linguistic intelligence questionnaire sheet. The data analysis technique used is Two Way Anova on data that has been normally distributed and homogeneous. The results obtained by testing hypotheses: (1) the average of the children achievement taught by Collaborative Strategic Reading (CSR) strategy is higher than students taught by Directed, Reading, Thinking, Activity (DRTA) strategy, which indicated by Fc $=8,65$ $>\mathrm{Ft}=3,98$ at significance level $\alpha=0,05$ with $\mathrm{df}(1.68)$; (2) the average of the students who have the ability of high linguistic intelligence is higher than the students who have low linguistic intelligence, which is indicated by $\mathrm{Fc}=9,38$ $>\mathrm{Ft}=3,98$ at significance level $\alpha=0,05$ with $\mathrm{df}(1.68)$; (3) there is interaction learning strategy and linguistic intelligence to the Understanding English text outcomes student, which is indicated by $\mathrm{Fc}=5,58>\mathrm{Ft}=3,98$ at significance level $\alpha=0.05$ with $\mathrm{df}(1,68)$. Based on the data analysis it can be concluded that Collaborative Strategic Reading (CSR) strategy is better than the Directed, Reading, Thinking, Activity (DRTA) strategy in improving students' learning outcomes of understanding English texts. Students who have a high linguistic intelligence obtain higher English learning outocmes than the students who have low linguistic intelligence.
\end{abstract}

Keywords: collaborative reading strategic, directed, reading, thinking, activity, linguistic intelligence, student learning outcomes.

\section{INTRODUCTION}

Learning English in schools is believed by the government as an effort to face the flow of globalization for every student so that graduates are able to communicate and have discourse in the world of work globally [1]. Learning English is a combination of several processes carried out through the collaboration of teachers (teachers) and language learners (students) in schools. Based on [2], the Primary and Secondary Education Units that regulate the scope of English subjects in SMA should stipulate that the English competency standards that must be mastered by students include the following: (1) the ability to understand and 
create various short functional texts and monologues and essays, (2) the ability to understand the structure of interpersonal, transactional, and functional texts, (3) the ability to discourse, namely the ability to understand, and (4) mastery of linguistic elements, complex phrases, and modalities.

However, in reality, it is known that the achievement of English learning objectives is still far from what is expected. Based on the results of [3] it is known that Indonesia is ranked 116th out of 189 countries in the world regarding the number of children aged 15-24 who can understand short sentences through reading and writing every day. This shows that there are still many Indonesian children who show low interest in reading. Reading comprehension in this case is very important to be mastered by students where some students even though they are able to read the text with fluent pronunciation, but they are not able to find the main idea and detailed information from the text correctly. In addition, there were a number of significant problems related to the process of teaching and learning to read and understand English texts. Students are known to have difficulty identifying information from reading texts. All these difficulties make students misunderstand until finally they fail to form the meaning of words in understanding the reading text. This is as evidenced by the average score of English from SMA Negeri 2 Medan and SMA Negeri 5 Medan which has not reached the maximum result of the Minimum Passing Grade (KKM), which is 70. Low learning outcomes are closely associated with the learning process. To improve student learning outcomes, it is necessary to make a change in the learning process, especially related to strategies or learning methods that have a major influence on the teaching and learning process, apart from approaches, methods and techniques.

One strategy that can be applied in learning English reading skills in schools is the Collaborative Strategic Reading (CSR) strategy. Research conducted by [4] suggests that this strategy has proven to have a positive impact on students' reading comprehension where after the implementation of this strategy, those who previously were not able to summarize a reading text in their own sentences, became better with this ability. In addition, the application of this strategy was also found to be beneficial for teachers because it made it easier for teachers to guide students to work cooperatively in a team of five or more depending on the number of students in the class. In line with research conducted by [5] it is stated that this CSR strategy has proven to be successful in improving students' ability to understand the content of reading texts and enriching students' vocabulary in interpreting the author's intentions in English reading texts. This is supported by the findings from [6] that this strategy can help students develop their ability to work together or collaborate considering that a discussion group will make the reading comprehension process more comfortable and easier. The study of [7] explained that this strategy consists of four stages. The first stage is preview, which is the strategy used to dig up information before reading the text. The second stage is click clunk, which is the stage to dig up information in the text when they read the text. Furthermore, the third stage is get the gist which in this stage, students will conclude the main ideas of the readings they have read. The last is wrap up, where at this stage students will make questions and conclude about what they have learned. Likewise, with what was stated by [8] that the implementation of this CSR strategy will make students able to understand reading because they will learn it through direct experience. Students in this strategy will be actively involved in making and responsible for the results obtained. In addition, students will be given learning materials according to their needs so that they will be motivated to learn the subject matter. The Directed, Reading, Thinking and Activity (DRTA) strategy in learning English on the other hand will motivate students' effort and concentration by engaging them intellectually and encouraging them to formulate questions and hypotheses, process information, and evaluate temporary solutions. The DRTA strategy can be used by teachers in reading comprehension materials.

Furthermore, an important factor determining the success of students in learning is linguistic intelligence. Linguistic intelligence is the ability to use words skillfully and express concepts fluently. This intelligence is demonstrated by sensitivity to the meaning and order of words, as well as the ability to make various uses of language.

Linguistic intelligence is the intelligence in using language or words effectively, whether spoken or written. This intelligence is related to language, reading and writing activities. A child who is good at language does not mean mastering many languages, but the child has the ability to process language. A child can become a writer, poet, or even an orator because he has this linguistic intelligence. Referring to this explanation, it is concluded that there are two factors that influence the success of the learning process in understanding reading texts, namely learning strategies and factors of students' linguistic intelligence.

Summarizing the above description, to improve the quality of reading comprehension learning, it is necessary to conduct a study that aims to determine the effect of using learning strategies that are in accordance with the linguistic intelligence of students in learning, more precisely in this study is the understanding of English texts. 


\section{METHOD}

This research took place at at SMA NEGERI 2 Medan and SMA Negeri 5 Medan in August 2020 which consisted of 6 meetings where the treatment schedule was determined by adjusting the schedule for the first semester of English study for the 2020/2021 school year. This research method was quasi experimental research and was conducted by applying an experimental design with a factorial of $2 \times 2$.

The subjects selected in this study were students of SMA Negeri 2 and SMA Negeri 5 Medan. Thus, the population in this study were all students of grade XI MIPA SMA Negeri 2 Medan which consisted of 360 students as the total students of 10 parallel classes and all students of grade XI MIPA SMA Negeri 5 Medan which consisted of 258 students as the total students of 8 parallel classes. The number of research samples taken from grade XI was 72 students, namely grade XI MIPA 3 at SMA Negeri 2 Medan and XI MIPA 1 at SMA Negeri 5 Medan. The samples taken consisted of two groups, namely an experimental class group in which the CSR learning strategies was applied and one class group where the DRTA strategy was applied. Teachers who were assigned to carry out the learning methods were given directions on how to use learning strategies in the learning process. Based on students' linguistic intelligence in learning English, the experimental class is divided into groups of students who have high linguistic intelligence and low linguistic intelligence in learning English. The sampling technique used in this research was Cluster Random (Arikunto, 2010). Before the experiment was carried out, the two sample groups were first given a questionnaire to determine the students' linguistic intelligence. Students' linguistic intelligence is categorized as high and low linguistic intelligence.

Data collection on reading comprehension learning outcomes is in the form of learning outcomes tests, while data collection related to students' linguistic intelligence is carried out using a linguistic intelligence test called TIMI (the telee inventory of multiple intelligences) made by multiple intelligence expert from America, Howard Gardner. This test is then modified according to the need to be further assessed by a psychologist, Dhani Kusumawardhana, S.Psi. to ensure the validity of the test instrument whether it can measure a person's level of linguistic intelligence. However, the form of the instrument is still guided by the indicators described by [9].

The data analysis technique used in this research is descriptive analysis and inferential analysis. Descriptive analysis technique is intended to describe research data, which includes mean, median, mode, variance and standard deviation. Furthermore, the data will be presented in the form of a frequency distribution table and histogram. The inferential analysis technique is intended to test the hypothesis which was performed using a two-way analysis of variance (ANOVA) technique.

\section{RESULTS}

The Description of Data

The data described in this study are data on students' English language skills in classes that apply Collaborative Strategic Reading (CSR) and Directed, Reading, Thinking, Activity (DRTA) learning strategies. The details of the description of the data include the highest value, lowest value, average, median, mode, standard deviation, and variance.

\subsection{The Results of English Texts Comprehension Learned With Strategic Collaborative Reading (CSR) Learning Strategies}

Based on the data obtained, it was found that the lowest and highest test scores on the ability to understand English texts taught using the Collaborative Reading Strategic (CSR) learning strategy were 68 and 96, respectively, with an average score of 82.08. The median (Me) value obtained is 82.5, mode (Mo) 83.60, varians $\left(s^{2}\right) 49,11$ and standard deviation (s) 7,01. The complete data is presented in table 3.1 below.

Table 3.1 Frequency Distribution on Results of English Texts Comprehension Learned with Strategic Collaborative Reading (CSR) Learning Strategies

\begin{tabular}{llll}
\hline No & Interval Class & $\begin{array}{l}\text { Absolute } \\
\text { Frequency }\end{array}$ & $\begin{array}{l}\text { Relative } \\
\text { frequency (\%) }\end{array}$ \\
\hline $\mathbf{1}$ & $68-72$ & 4 & 11,11 \\
$\mathbf{2}$ & $73-77$ & 5 & 13,89 \\
$\mathbf{3}$ & $78-82$ & 11 & 30,56 \\
$\mathbf{4}$ & $83-87$ & 9 & 25,00 \\
$\mathbf{5}$ & $88-92$ & 4 & 11,11 \\
$\mathbf{6}$ & $93-97$ & 3 & 8,33 \\
Total & 36 & 100,00 \\
\hline
\end{tabular}

Based on table 3.1, it is known that the average value is in the class interval $78-82$ with 11 students (30.56\%). Students who get scores below the average are $9(25 \%)$, while those who have scores above the average are 16 $(44.44 \%)$. Thus, the frequency distribution of the test scores on the results of English texts reading comprehension ability taught using the Collaborative Strategic Reading (CSR) learning strategy can be described as follows: 


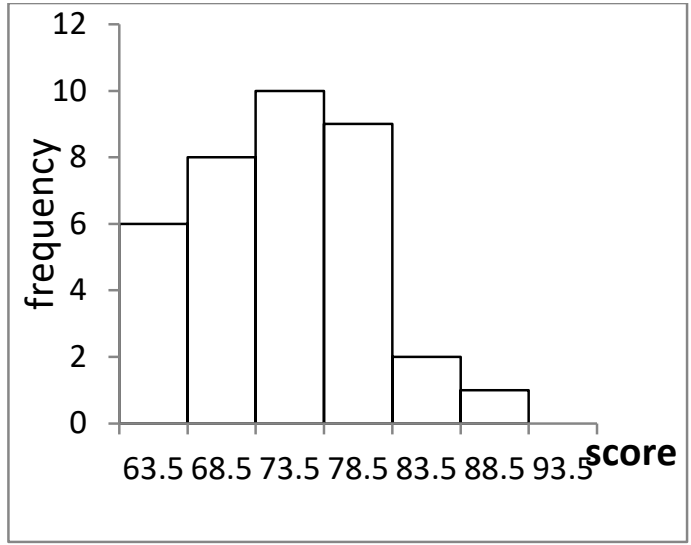

Figure 3.1. Test Score Histogram of English Text Comprehension Results Learned With Collaborative Strategic Reading (CSR) Learning Strategy

\subsection{The Results of English Texts Comprehension Learned with Directed, Reading, Thinking, Activity (DRTA) Learning Strategies}

Based on the data obtained, it is known that the lowest score of the English text reading comprehension test that was taught using the Directed, Reading, Thinking, Activity (DRTA) learning strategy was 64, while the highest was 93 with the average score which was 75.44. Furthermore, the median (Me) obtained was 75.5, mode (Mo) 76.83, variance $\left(\mathrm{s}^{2}\right) 41.11$ and standard deviation (s) 6.41. In details, the data is presented in the following table.

Table 3.2. Frequency Distribution on Results of English Texts Comprehension Learned with Directed, Reading, Thinking, Activity (DRTA) Learning Strategies

\begin{tabular}{cccc}
\hline No. & $\begin{array}{l}\text { Interval } \\
\text { Class }\end{array}$ & $\begin{array}{c}\text { Absolute } \\
\text { frequency }\end{array}$ & $\begin{array}{c}\text { Relative } \\
\text { Frequency } \\
(\%)\end{array}$ \\
\hline $\mathbf{1}$ & $64-68$ & 6 & 16,67 \\
$\mathbf{2}$ & $69-73$ & 8 & 22,22 \\
$\mathbf{3}$ & $74-78$ & 10 & 27,78 \\
$\mathbf{4}$ & $79-83$ & 9 & 25,00 \\
$\mathbf{5}$ & $84-88$ & 2 & 2,78 \\
$\mathbf{6}$ & $89-93$ & 1 & 5,56 \\
& Total & 36 & 100,00 \\
\hline
\end{tabular}

From table 3.2 above, it is known that the average value is in the class interval 74-78 with a total of 10 students $(27.78 \%)$. Students who scored below the average were 14 students (38.89\%), while those who scored above the average were 12 students $(33.34 \%)$. The frequency distribution of English text reading comprehension test scores taught using the DRTA learning strategy is described as follows:

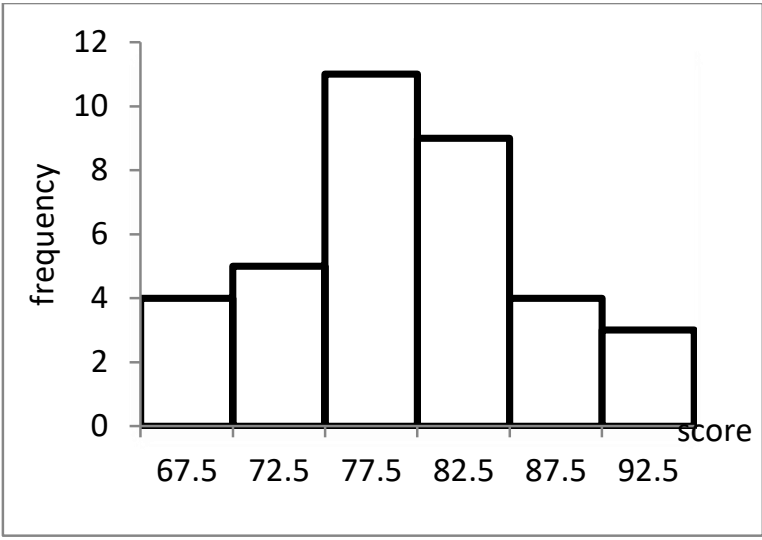

Figure 3.2. Test Score Histogram of English Text Comprehension Results Learned Directed, Reading,Thinking, Activity (DRTA) Learning Strategies

\subsection{The Results of English Texts Reading Comprehension on Students who have High Linguistic Intelligence}

Based on the data obtained, it is known that the test score of the English text reading comprehension which has the lowest high linguistic intelligence is 68 , the highest is 96 and the average value is 80.54 . Then, the value of Median (Me) 79.55, mode (Mo) 78.21, variance (s2) 51.09 and standard deviation (s) 7.15. For more details, the data can be seen in table 3.3. following.

Table 3.3. Frequency Distribution of the English Texts Reading Comprehension Test Result on Student with High Linguistic Intelligence

\begin{tabular}{cccc}
\hline No. & $\begin{array}{c}\text { Interval } \\
\text { Class }\end{array}$ & $\begin{array}{c}\text { Absolute } \\
\text { frequency }\end{array}$ & $\begin{array}{c}\text { Relative } \\
\text { Frequency } \\
(\mathbf{\%})\end{array}$ \\
\hline $\mathbf{1}$ & $68-72$ & 4 & 10,81 \\
$\mathbf{2}$ & $73-77$ & 10 & 27,03 \\
$\mathbf{3}$ & $78-82$ & 11 & 29,73 \\
$\mathbf{4}$ & $83-87$ & 5 & 13,51 \\
$\mathbf{5}$ & $88-92$ & 4 & 10,81 \\
$\mathbf{6}$ & $93-97$ & 3 & 8,11 \\
& Total & 37 & 100,00 \\
\hline
\end{tabular}

From table 3.3 above, it can be seen that the average value is in the class interval 78-82 with a total of 11 students $(29.73 \%)$. Students who scored below the average were 14 students $(37.84 \%)$, while those who scored above the average were 12 students (32.43\%). The frequency distribution of the English texts reading comprehension results that have high linguistic intelligence is described as follows. 


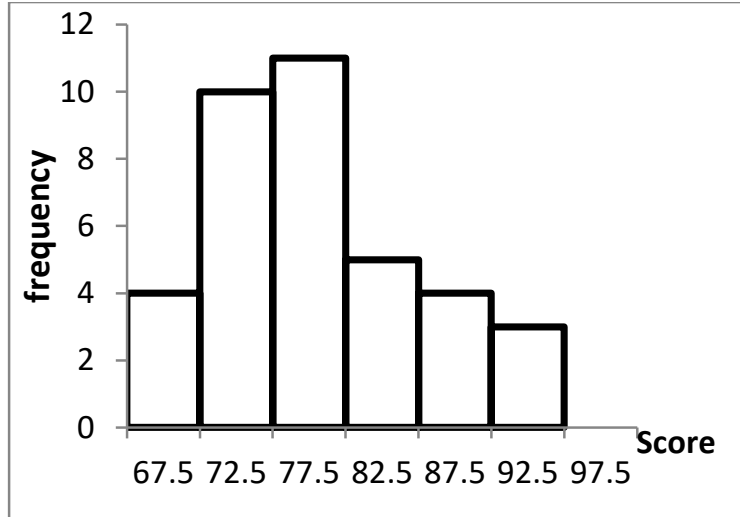

Figure 3.3. Test Score Histogram of English Text Reading Comprehension Results on Students with High Linguistic Intelligence

\subsection{The Results of English Texts Reading Comprehension on Students with Low Linguistic Intelligence}

Based on the data obtained, it is known that the lowest test scores on the results of English texts reading comprehension on students that have low linguistic intelligence are 64. Meanwhile, the highest score obtained is 93 with the average value of 75.14 . The value of Median (Me) obtained in this case is 75.06, mode (Mo) 79.13, variance (s2) 44.83 and standard deviation (s) 6.66. In details, the data is presented in table 3.4 below.

Table 3.4. Frequency Distribution of English Texts Reading Comprehension Results on Students with Low Linguistic Intelligence

\begin{tabular}{cccc}
\hline No. & $\begin{array}{c}\text { Interval } \\
\text { Class }\end{array}$ & $\begin{array}{c}\text { Absolute } \\
\text { Frequency }\end{array}$ & $\begin{array}{c}\text { Relative } \\
\text { Frequency (\%) }\end{array}$ \\
\hline $\mathbf{1}$ & $64-68$ & 7 & 20,00 \\
$\mathbf{2}$ & $69-73$ & 8 & 22,86 \\
$\mathbf{3}$ & $74-78$ & 9 & 25,71 \\
$\mathbf{4}$ & $79-83$ & 8 & 22,86 \\
$\mathbf{5}$ & $84-88$ & 2 & 5,71 \\
$\mathbf{6}$ & $89-93$ & 1 & 2,86 \\
& Total & 35 & 100,00 \\
\hline
\end{tabular}

From table 3.4 , it is presented that the average value is in the class interval of 74-78 with a total of 9 students $(25.71 \%)$. Students who obtained scores below the average are $15(42.86 \%)$, while students who obtained scores above the average are 11 (31.43\%). The frequency distribution of the English texts reading comprehension results on students with low linguistic intelligence can be described as follows.

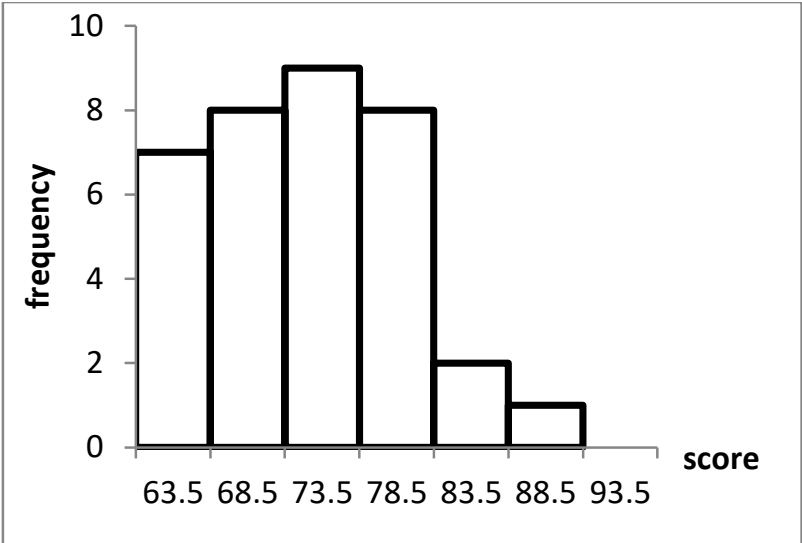

Figure 3.4. Test Score Histogram of English Text Reading Comprehension Results on Students with Low Linguistic Intelligence

\subsection{The Results of English Texts Reading Comprehension in Students who are taught with CSR Learning Strategies and have High Linguistic Intelligence}

Based on the data obtained, it is known that the test scores on the results of reading comprehension of English texts of students who are taught with CSR learning strategies and have high linguistic intelligence, the lowest is 68 with the highest score obtained is 96 . The average value in this case is 85,55 . The median (Me), mode (Mo), variance (s2)m and standard deviation (s) values obtained are 86.95, 88.5, 57.44 and 7.58 , respectively. More details, these data are presented in table 3.5. following.

Table 3.5. Frequency Distribution of English Text Reading Comprehension Results in Students who are taught with CSR Learning Strategies and have High Linguistic Intelligence

\begin{tabular}{cccc}
\hline No. & $\begin{array}{c}\text { Interval } \\
\text { Class }\end{array}$ & $\begin{array}{c}\text { Absolute } \\
\text { Frequency }\end{array}$ & $\begin{array}{c}\text { Relative } \\
\text { Frequency (\%) }\end{array}$ \\
\hline $\mathbf{1}$ & $68-73$ & 1 & 5,00 \\
$\mathbf{2}$ & $74-79$ & 3 & 15,00 \\
$\mathbf{3}$ & $80-85$ & 7 & 35,00 \\
$\mathbf{4}$ & $86-91$ & 5 & 25,00 \\
$\mathbf{5}$ & $92-96$ & 4 & 20,00 \\
& Total & 20 & 100,00 \\
\hline
\end{tabular}

From table 3.5 above, it can be seen that the average value is in the 80-85 interval class with a total of 7 students $(35 \%)$. Students with grades below the average are $4(20 \%)$, while the students with grades above the average are $9(45 \%)$. The frequency distribution of the the English text reading comprehension results in students taught with CSR learning strategies and have high linguistic intelligence can be described as follows. 


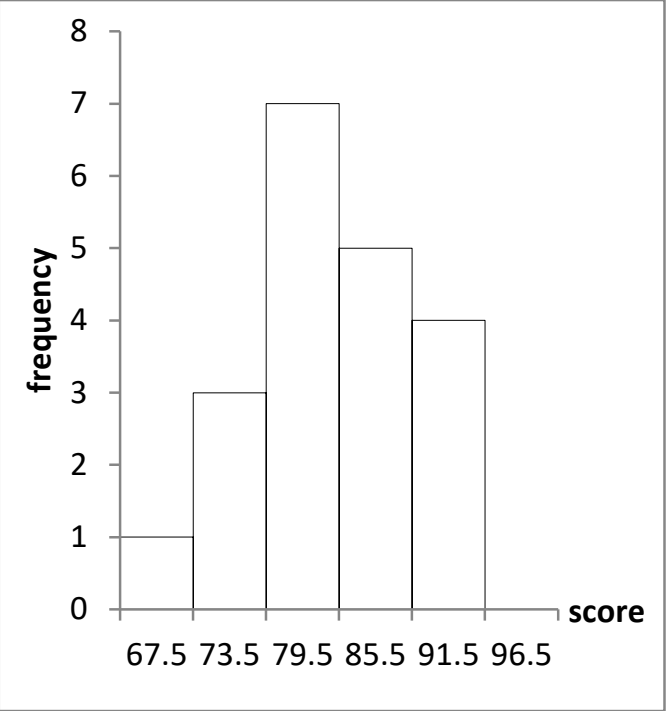

Figure 3.5. Test Score Histogram of English Text Reading Comprehension Results on Students taught with CSR learning strategies and have High Linguistic Intelligence

\subsection{The Results of English Text Reading Comprehension in Students taught with CSR Learning Strategies and have Low Linguistic Intelligence}

Based on the data obtained, it is known that the lowest test scores on the results of English text reading comprehension of students taught with CSR learning strategies and have the low linguistic intelligence is 64, while the highest score obtained is 82 with the average value which is 77.75. The median (Me), mode (Mo), variance (s2) and standard deviation (s) values obtained are $73.5,73.32,18.07,4.25$, respectively. The data is presented in more detail in table 3.6

Table 3.6. Frequency Distribution of English Text Reading Comprehension Results in Students taught with CSR Learning Strategies and have Low Linguistic Intelligence

\begin{tabular}{cccc}
\hline No. & $\begin{array}{c}\text { Interval } \\
\text { Class }\end{array}$ & $\begin{array}{c}\text { Absolute } \\
\text { Frequency }\end{array}$ & $\begin{array}{c}\text { Relative } \\
\text { Frequency (\%) }\end{array}$ \\
\hline $\mathbf{1}$ & $64-67$ & 1 & 6,25 \\
$\mathbf{2}$ & $68-71$ & 2 & 12,50 \\
$\mathbf{3}$ & $72-75$ & 3 & 18,75 \\
$\mathbf{4}$ & $76-79$ & 8 & 50,00 \\
$\mathbf{5}$ & $80-83$ & 2 & 12,50 \\
& Total & 16 & 100,00 \\
\hline
\end{tabular}

From table 3.6 above, it can be seen that the average value is in the class interval 76-79 with a total of 8 students $(50 \%)$. Students with scores below the average are $6(37.50 \%)$, while students with scores above the average are $2(12.50 \%)$. The frequency distribution of the English text reading comprehension results in students taught with CSR learning strategies and have low linguistic intelligence can be described as follows.

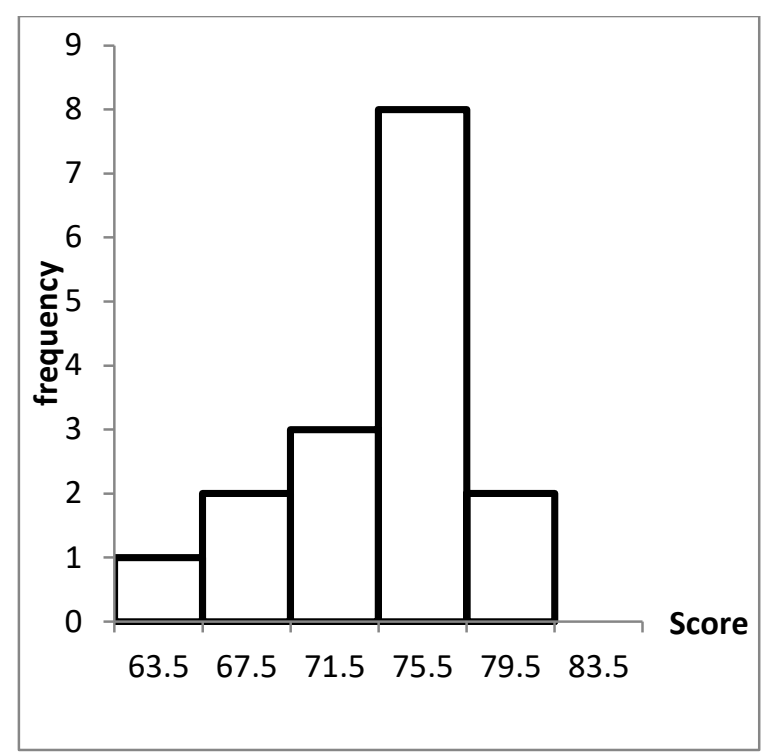

Figure 3.6. Test Score Histogram of English Text Reading Comprehension Results on Students taught with CSR learning strategies and have Low Linguistic Intelligence

\subsection{The Results of English Text Reading Comprehension in Students taught with DRTA Learning Strategies and have High Linguistic Intelligence}

Based on the data obtained, it is known that the lowest test scores on the results of English text reading comprehension of students taught with DRTA learning strategies and have the low linguistic intelligence is 68, while the highest score obtained is 82 with the average value which is 75.18 . The median (Me), mode (Mo), variance (s2) and standard deviation (s) values obtained are $75,74.88,9.53,3.09$, respectively. The data is presented in more detail in table 3.7.

Table 3.7. Frequency Distribution of English Text Reading Comprehension Results in Students taught with DRTA Learning Strategies and have High Linguistic Intelligence

\begin{tabular}{cccc}
\hline No. & $\begin{array}{c}\text { Interval } \\
\text { Class }\end{array}$ & $\begin{array}{c}\text { Absolute } \\
\text { Frequency }\end{array}$ & $\begin{array}{c}\text { Relative } \\
\text { Frequency (\%) }\end{array}$ \\
\hline $\mathbf{1}$ & $68-70$ & 1 & 5,88 \\
$\mathbf{2}$ & $71-73$ & 3 & 17,65 \\
$\mathbf{3}$ & $74-76$ & 9 & 52,94 \\
$\mathbf{4}$ & $77-79$ & 2 & 11,76 \\
$\mathbf{5}$ & $80-82$ & 2 & 11,76 \\
& Total & 17 & 100,00 \\
\hline
\end{tabular}

From table 3.7 above, it can be seen that the average value is in the class interval 76-79 with a total of 9 students $(52,94 \%)$. Students with scores below the average are $4(23.53 \%)$, while students with scores above the average are also $4(23.53 \%)$. The frequency distribution of the English text reading comprehension results in students taught with DRTA learning strategies and have high linguistic intelligence can be described as follows. 


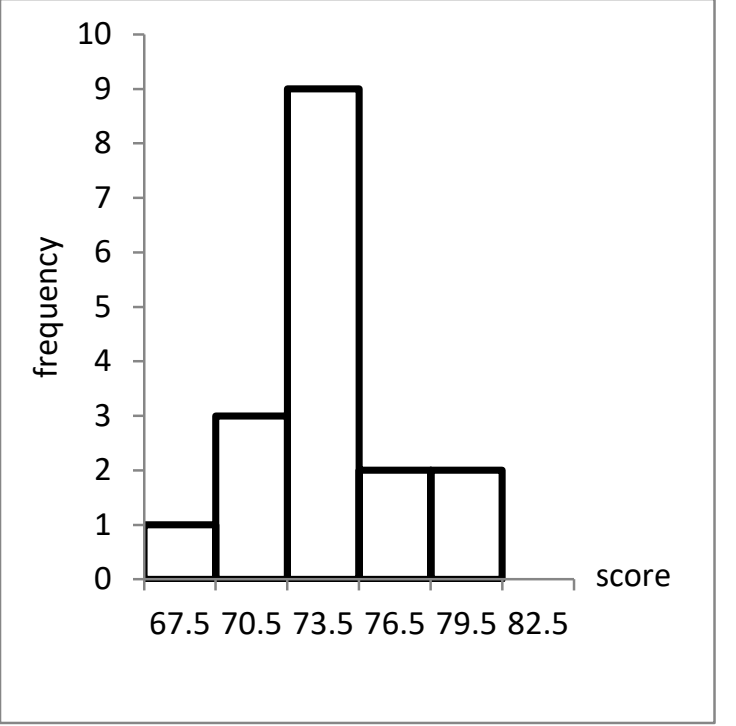

Figure 3.7. Test Score Histogram of English Text Reading Comprehension Results on Students taught with DRTA learning strategies and have High Linguistic Intelligence

\subsection{The Results of English Text Reading Comprehension in Students taught with DRTA Learning Strategies and have Low Linguistic Intelligence}

Based on the data obtained, it is known that the lowest test scores on the results of English text reading comprehension of students taught with DRTA learning strategies and have the low linguistic intelligence is 64, while the highest score obtained is 95 with the average value which is 77.83 . The median (Me), mode (Mo), variance (s2) and standard deviation (s) values obtained are $77,83,78,02,43,58$ and 6,60 , respectively. The data is presented in more detail in table 3.8 .

Table 3.8. Frequency Distribution of English Text Reading Comprehension Results in Students taught with DRTA Learning Strategies and have Low Linguistic Intelligence

\begin{tabular}{cccc}
\hline No. & $\begin{array}{c}\text { Interval } \\
\text { Class }\end{array}$ & $\begin{array}{c}\text { Absolute } \\
\text { Frequency }\end{array}$ & $\begin{array}{c}\text { Relative } \\
\text { Frequency (\%) }\end{array}$ \\
\hline $\mathbf{1}$ & $64-69$ & 2 & 10,53 \\
$\mathbf{2}$ & $70-75$ & 4 & 21,05 \\
$\mathbf{3}$ & $76-81$ & 9 & 47,37 \\
$\mathbf{4}$ & $82-87$ & 2 & 10,53 \\
$\mathbf{5}$ & $88-93$ & 2 & 10,53 \\
& Total & 19 & 100,00 \\
\hline
\end{tabular}

From table 3.8 above, it can be seen that the average value is in the class interval 76-81 with a total of 9 students $(47.37 \%)$. Students with scores below the average are $6(31.58 \%)$, while students with scores above the average are $4(21.06 \%)$. The frequency distribution of the English text reading comprehension results in students taught with DRTA learning strategies and have low linguistic intelligence can be described as follows.

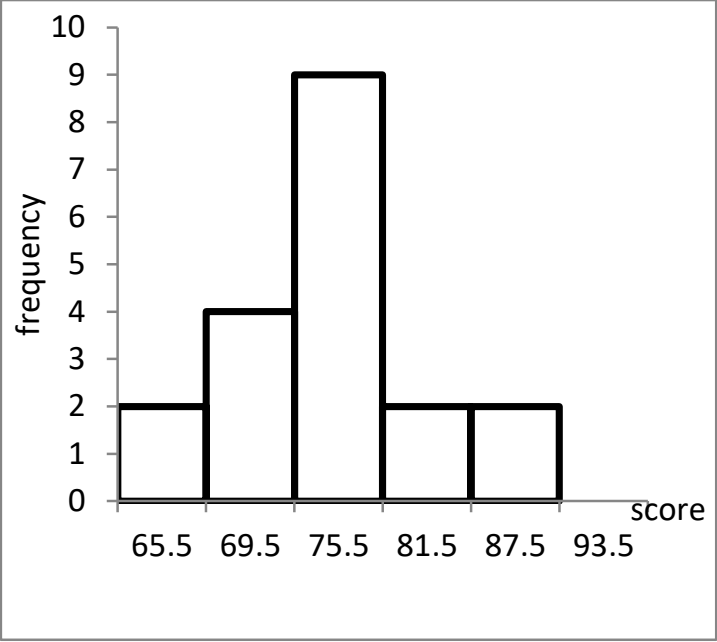

Figure 3.8. Test Score Histogram of English Text

Reading Comprehension Results on Students taught with DRTA learning strategies and have Low Linguistic Intelligence

\section{Testing Requirements Analysis Normality test}

The data normality test is used to determine whether the sample comes from a normally distributed population. The test was carried out using the Lilliefors test. The data normality test of the results of understanding English texts taught with the Collaborative Strategic Reading (CSR) learning strategy has a value of $L_{o}=0.138$ and $L_{t}=0.148$ at a significant level of 0.05 . Thus, $L_{o}<L_{t}$, so it can be concluded that the data on the results of English text reading comprehension on students taught with Collaborative Strategic Reading (CSR) learning strategies are normally distributed.

Meanwhile, the results of the calculation of the normality test of the results of understanding English texts with the DRTA learning strategy have a value of $L_{o}=0.121$ and $L_{t}=0.148$ at a significant level of 0.05 . Therefore, $L_{o}<L_{t}$ or in other words, it can be concluded that the data on the results of English text reading comprehension on students who have high linguistic intelligence are normally distributed.

The normality test of data related to the English text reading comprehension in students with high linguistic intelligence resulted in $L_{o}=0.104$ and $L_{t}=0.146$ at a significant level of 0.05 . Thus, $L_{o}<L_{t}$, so it can be concluded that the English texts reading comprehension in students who have high linguistic intelligence is normally distributed.

In the results of the calculation of the normality test of data related to the English texts reading comprehension in students with low linguistic intelligence, the values obtained are $L_{o}=0.109$ and $L_{t}$ $=0.150$ at a significant level of 0.05 or in other words $L_{o}<L_{t}$. Thus, it can be concluded that the English texts reading comprehension in students who have low linguistic intelligence is normally distributed. 
The data normality test on the English texts reading comprehension in students who have high linguistic intelligence and are taught with the Collaborative Strategic Reading (CSR) learning strategy obtained a value of $L_{o}=0.112$ and $L_{t}=0.190$ at a significant level of 0.05 . Thus, $L_{o}<L_{t}$ so that it can be concluded that the English texts reading comprehension in students who are taught with CSR learning is normally distributed.

The calculation results of the normality test of data related to the English texts reading comprehension in students with high linguistic intelligence and taught with the DRTA learning strategy showed the value of $L_{o}=$ 0.092 and $L_{t}=0.206$ at a significant level of 0.05 . Thus, $L_{o}<L_{t}$ so that it can be concluded that the English texts reading comprehension in students with high linguistic intelligence and taught with the DRTA learning strategy is normally distributed.

In the calculation results of the data normality test related to the English texts reading comprehension in students with low linguistic intelligence and taught with CSR learning strategies, showed that the values of $L_{o}=$ 0.147 and $L_{t}=0.213$ at a significant level of 0.05 . In other words, these results indicate that $L_{o}<L_{t}$, so it can be concluded that the data on the English text reading comprehension in students with low linguistic intelligence and taught with CSR learning strategies are normally distributed.

The results of the data normality testing related to the English texts reading comprehension in students with low linguistic intelligence and taught by the DRTA learning strategy show the value of $L_{o}=0.169$ and $L_{t}$ $=0.195$ at a significant level of 0.05 . Thus, $L_{o}<L_{t}$, so it can be concluded that the data on the English texts reading comprehension in students with low linguistic intelligence and taught using the DRTA strategy are normally distributed.

\section{Homogeneity Test}

The purpose of the homogeneity of variance test is to find out whether the sample variance comes from a homogeneous population or not. Homogeneity test was conducted by comparing the variance of learning outcomes data between learning strategies and linguistic intelligence. The calculation of the homogeneity test in the group taught with the CSR learning strategy and the DRTA strategy was carried out using the Fisher test.

The homogeneity test of data related to the English texts reading comprehension in students taught with CSR learning strategies and DRTA learning strategies and resulted in $\mathrm{F}_{\text {count }}=1.195<\mathrm{F}_{\text {table }}=1.75$ indicates that the English texts reading comprehension in students taught by CSR learning strategies and learning strategies DRTA has relatively the same variance (homogeneous).

Furthermore, the homogeneity test related to the English texts reading comprehension in students who have high linguistic intelligence and low linguistic intelligence is carried out using fisher. The results of this calculation obtain $\mathrm{F}_{\text {count }}=1.140$ and $\mathrm{F}_{\text {table }}=1.74$. These results indicate that the English texts reading comprehension in students who have high linguistic intelligence and low linguistic intelligence have relatively the same variance (homogeneous).

In testing the homogeneity of the sample taught with CSR and DRTA learning strategies and having high and low linguistic intelligence, it was carried out simultaneously using the Bartlet test. The results of this test obtain $\mathrm{X}_{\text {count }}^{2}=7.78$ and $\mathrm{X}_{\text {table }}^{2}=7.82$ at a significant level $=0.05$ with $\mathrm{dk}=3$. The calculation results state that $X^{2}$ count $=7.78<X_{\text {table }}^{2}=7.815$. In other words, it can be concluded that the samples come from populations that have relatively the same (homogeneous) variance.

\section{Hypothesis testing}

First hypothesis

The data analysis technique used to test the research hypothesis is the two-way analysis of variance (ANOVA). The required data to calculate ANOVA is presented in Table 3.9 below:

Table 3.9. Summary of Research Result Data

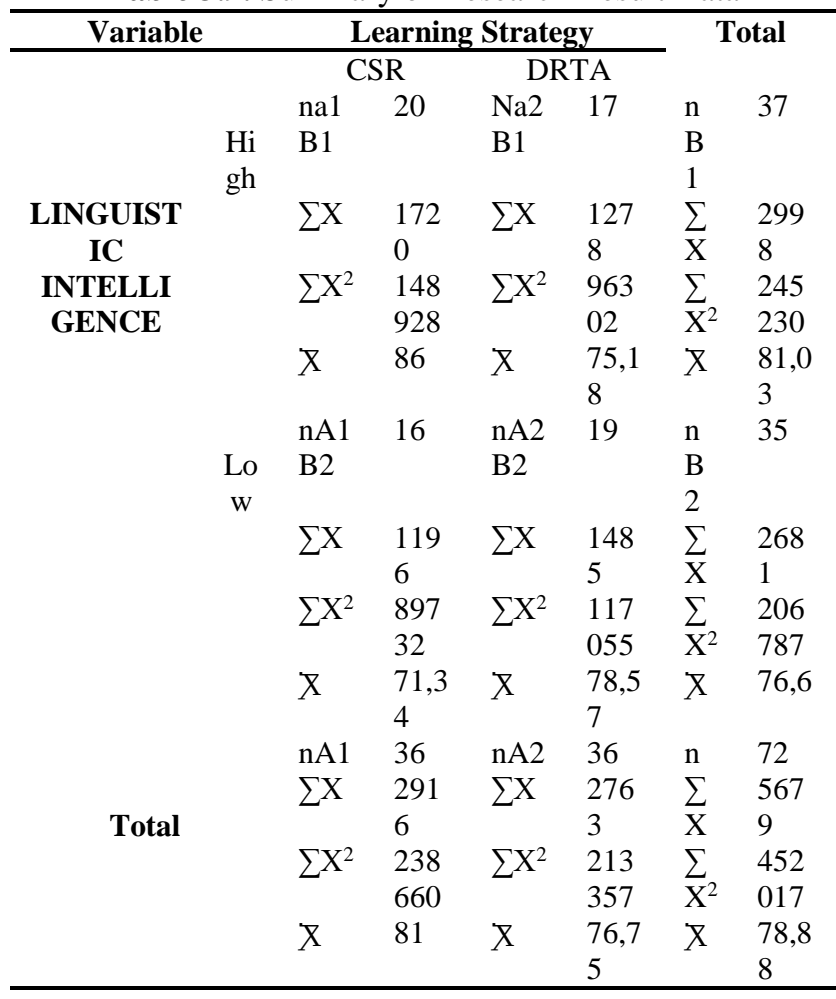

Overall, the results of the ANOVA test for hypothesis testing are presented in Table 3.10 below.

Table 3.10. Summary of Overall ANOVA Results on English Text Reading Comprehension

\begin{tabular}{cccccc}
$\begin{array}{c}\text { Source of } \\
\text { Variation }\end{array}$ & $\mathbf{D k}$ & $\mathbf{J K}$ & $\mathbf{R J K}$ & $\mathbf{F}_{\mathbf{h}}$ & $\begin{array}{c}\mathbf{F}_{\mathbf{t}} \\
(\mathbf{1 . 6 8}) \\
(\boldsymbol{\alpha}= \\
\mathbf{0 , 0 5})\end{array}$ \\
\hline $\begin{array}{c}\text { Learning } \\
\text { Strategy (A) } \\
\begin{array}{c}\text { Linguistic } \\
\text { Intelligence }\end{array}\end{array}$ & 1 & 325,12 & 325,12 & 8,65 & 3,98 \\
\hline
\end{tabular}




\begin{tabular}{cccccc}
\hline $\begin{array}{c}(\mathbf{B}) \\
\begin{array}{c}\text { Interaction } \\
\text { (AB) }\end{array}\end{array}$ & 1 & 2207,49 & 2207,49 & 58,73 & 3,98 \\
Error & 68 & 2556 & 37,59 & - & - \\
Total & 71 & 5441,11 & & & - \\
\hline
\end{tabular}

Where:

$\mathrm{Dk}=$ degrees of freedom

$\mathrm{JK}=$ Sum of squares

RJK = Average sum of squares

\section{Hypothesis 1}

The statistical hypotheses tested are:

$\mathrm{H}_{\mathrm{o}}: \mu \mathrm{B} 1 \leq \mu \mathrm{B} 2$

$\mathrm{H}_{\mathrm{O}}: \mu \mathrm{B} 1 \geq \mu \mathrm{B} 2$

Based on the results of hypothesis testing, the results of the calculation of linguistic intelligence data are obtained as indicated by $\mathrm{F}_{\text {count }}=9.38>\mathrm{F}_{\text {table }}=3.98$. These results indicate that the null hypothesis (Ho) is rejected and the alternative hypothesis (Ha) is accepted. Thus, the research hypothesis which states that the English texts reading comprehension of students who have high linguistic intelligence is better than students who have low linguistic intelligence is proven to be true.

\section{Hypothesis 3}

The statistical hypotheses tested are:

$\mathrm{H}_{\mathrm{o}}: \mathrm{A}><\mathrm{B}=0$

$\mathrm{H}_{\mathrm{a}}: \mathrm{A}><\mathrm{B} \neq 0$

Based on the results of hypothesis testing, the results of the calculation of the interaction data of learning strategies and linguistic intelligence are obtained, where $\mathrm{F}_{\text {count }}=58.73>3.98$, so the Zero Hypothesis $\left(\mathrm{H}_{0}\right)$ is rejected and the Alternative Hypothesis $\left(\mathrm{H}_{\mathrm{a}}\right)$ is accepted, thus the research hypothesis which states that there is an interaction between learning strategies and linguistic intelligence in influencing learning outcomes has been proven true.

Since the interaction between learning strategies and linguistic intelligence which turned out to have an effect on students' ability to understand English texts was found, it was necessary to carry out a post hoc test so that which sample had average English text reading comprehension ability which was different can be known. To see the form of interaction between learning strategies and linguistic intelligence in influencing the ability of English texts reading comprehension, further testing using the Scheffe test needs to be done. The acceptance criteria is if $F_{\text {count }}>F_{\text {table }}$ which indicates that the hypothesis is tested significantly. Based on the results of the Scheffe test, it is known that there are 6 (six) pairs of statistical hypotheses as follows:

1) Scheffe test results showed that $F_{\text {count }}=29.30>$ $\mathrm{F}_{\text {table }}=2.74$ thus giving the decision that Ho is rejected. Thus, the results of the study stated that the average ability of English texts reading comprehension of students who were taught with the CSR learning strategy and high linguistic intelligence was higher than the average ability of students who were taught with the DRTA learning strategy and high linguistic intelligence has been proven.

2) Scheffe test results showed that $F_{\text {count }}=54.48$ $>F_{\text {table }}=2.74$ so that it gives the decision that Ho is rejected. Thus, the results of the study stated that the average ability of English texts reading comprehension of students who were taught with the CSR learning strategy and a high level of linguistic intelligence was higher than the average ability of understanding English texts of students who were taught with the DRTA learning strategy and the level of intelligence Low linguistics has been proven.

3) Scheffe test results showed that $F_{\text {count }}=13.04>$ $\mathrm{Ft}_{\mathrm{able}}=2.74$, thus giving a decision that $\mathrm{Ho}$ is rejected. Thus, the results of the study which stated that the students' average ability of English texts reading comprehension taught using CSR learning strategies and high linguistic intelligence was higher than those who are taught by CSR learning strategies and low linguistic intelligence has been proven.

4) Scheffe test results showed that $F_{\text {count }}=54.48>$ $\mathrm{F}_{\text {table }}=2.74$ which indicates that Ho is rejected. Thus, the results of the study which stated that the average ability to understand English texts of students who were taught with CSR learning strategies and high linguistic intelligence levels was higher than students taught with DRTA learning strategies and low linguistic intelligence levels had been proven.

5) Scheffe test results showed that $F_{\text {count }}=13.04>$ $\mathrm{F}_{\text {table }}=2.74$, thus indicating that Ho is rejected. Thus, the research results which state that the average ability of English texts reading comprehension taught using CSR learning strategies and high linguistic intelligence is higher than students taught with CSR learning strategies and low linguistic intelligence has been proven.

6) Scheffe test results show that $F_{\text {count }}=3.87>$ $\mathrm{F}_{\text {table }}=2.74$, thus giving a decision that Ho is rejected. Thus, the results of the study which stated that the average English comprehension ability of students taught with the DRTA learning strategy and high linguistic intelligence was higher than students taught with CSR learning strategies and low linguistic intelligence had been proven true.

7) Scheffe test results showed that $F_{\text {count }}=3.87>$ $F_{\text {table }}=2.74$ which indicates that Ho is rejected. Thus, the results of the study which stated that the average ability of English texts reading comprehension of students taught with CSR learning strategies and high linguistic intelligence was higher than students taught with DRTA learning strategies and low linguistic intelligence had been verified. 
8) Scheffe test results showed that $F_{\text {count }}=14.19>$ $\mathrm{F}_{\text {table }}=2.74$, thus indicating that Ho is rejected. Thus, the results of the study which stated that the average ability of English texts reading comprehension of students who were taught with CSR learning strategies and linguistic intelligence was higher than students taught with DRTA learning strategies and low linguistic intelligence had been proven to be true.

In the end, by the discovery of the interaction between the variables of learning strategy and linguistic intelligence on the students' ability of English texts reading comprehension, an estimation graph can be given which shows the interaction as follows.

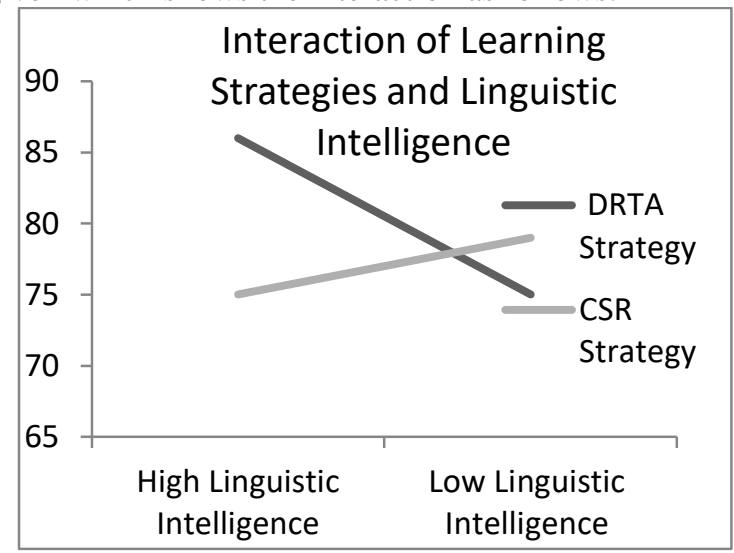

Figure 3.9. Interaction Model between Learning Strategies and Linguistic Intelligence on Ability of English Texts Reading Comprehension

\section{DISCUSSION OF RESEARCH RESULT}

\subsection{Differences in the Effect of Learning Strategies on Reading Comprehension of English Texts for High School Students in Medan}

Knowing the findings of this study, it was found that the reading comprehension of English texts of students who were taught with the Collaborative Strategic Reading (CSR) learning strategy was higher than those who were taught with the Directed, Reading, Thinking, Activity (DRTA) strategy. Anova statistical test revealed that $\mathrm{p}$ value $<=0.05$. These results indicate that $\mathrm{H}_{0}$ is rejected which indicates the influence of Collaborative Strategic Reading (CSR) learning strategies on reading comprehension of English texts for high school students in Medan. Referring to the results of the statistical test, it can be further explained that the Collaborative Strategic Reading (CSR) learning strategy that is applied will further improve the understanding of English texts for high school students in Medan.

The results of reading comprehension of English texts for high school students in Medan who are taught with Collaborative Strategic Reading (CSR) learning strategies are higher. This is because the Collaborative
Strategic Reading (CSR) learning strategy is a learning that is carried out based on the stages that students take in reading comprehension. This finding is reasonable because the Collaborative Strategic Reading (CSR) learning strategy applied is a learning that emphasizes collaborative learning so that it can improve students' reasoning power in understanding texts.

The application of Collaborative Strategic Reading (CSR) learning strategies in learning to read English text is an effort to train students to understand the learning materials that have been given. This strategy in learning instills certain habits in the form of collaboration or collaboration with classmates when reading comprehension tasks are given. Through regular practice, students are expected to be embedded in habits, speed, accuracy, perfection in doing something, which can further be used as a way to repeat the training material that has been presented while increasing language skills (Rusman, 2009).

CSR has advantages compared to other strategies in learning English, especially learning reading comprehension. By using CSR, all students are active and take part in discussion groups where each student has the opportunity to contribute as group members in learning and understanding reading texts. This is because in the CSR learning strategy, students in groups have their own duties and roles. However, in implementing CSR learning strategies, teachers may also experience difficulties in optimally controlling the entire group so that each student's responsibility is required to create conducive learning conditions. In addition, the weakness of this strategy is that the teacher takes a long time to prepare and design all learning activities so that the CSR learning strategy can run according to the procedure.

The findings of this study also support previous research conducted by Karabuga and Ebru (2013) on university students who found that CSR strategies had a positive impact on reading comprehension for these students. This strategy is also considered able to help students who were previously unable to summarize the text in their own sentences to become more skilled. This strategy is also proven to reduce the problems experienced by students in reading comprehension. Research from Fadhilah (2015) adds that this CSR strategy is able to improve students' ability to understand the content of reading texts and enrich students' vocabulary in interpreting the intent of English reading text writers. Research conducted by Bremer, Vaughn, Clapper and Kim (2002) found that this strategy benefits students in developing the ability to work together or collaborate so that discussion groups make the reading comprehension process more comfortable and easy. In this study, it was also found that the use of Collaborative Strategic Reading (CSR) learning strategies greatly encouraged the improvement of students' ability of English texts reading 
comprehension and increased students' ability in independent learning in English subjects of students at SMA Negeri 2 and SMA Negeri 5 Medan.

\subsection{Differences in the Effect of Linguistic Intelligence on Reading Comprehension of English Texts for High School Students in Medan}

Based on the results of the research conducted, it is known that the English learning outcomes of students who have high linguistic intelligence obtained the lowest score of 68 and the highest score of 96. In addition, the average score, mode, median, variance, and standard deviation were 80, 54, 78.21, 79.55, 51.09 and 7.15 , respectively. Meanwhile, the lowest and highest scores for students who have low linguistic intelligence are 64 and 93 where the average score, mode, median, variance, and standard deviation are $75.14,79.13,75.06,44.83$ and 6.66 , respectively. Thus, the second hypothesis has been proven that the level of students' linguistic intelligence has a significantly different effect on students' English learning outcomes where Fcount > Ftable. In other words, the second research hypothesis explains that $\mathrm{Ha}$ is accepted and Ho is rejected. This indicates the influence of linguistic intelligence on reading comprehension of English texts for high school students in Medan. Referring to the results of the statistical test, it can be further explained that the higher the students' linguistic intelligence, the higher the reading comprehension of English texts for high school students in Medan and vice versa.

Linguistic intelligence is one of the factors that influence the success of learning at school (Prasetyo dan Andriani, 2009), including learning English, especially in reading comprehension. Linguistic intelligence is the ability to use and process words effectively, both orally and in writing accompanied by the appropriate meaning. Meanwhile, the ability to understand reading English texts requires basic skills such as reasoning to analyze texts with linguistic intelligence.

Linguistic intelligence is the ability to use words skillfully and express concepts fluently. This intelligence is demonstrated by sensitivity to the meaning and order of words, as well as the ability to make various uses of language. Natural abilities related to language intelligence include spontaneous conversation, fairy tales, humor, jokes, persuading people to follow actions, giving explanations or teaching.

According to Sundawati (2014), linguistic intelligence is based on the concept of competence and performance where the concept of competence indicates an internal grammar that establishes the basis for a language theory and a model of linguistic giving with a competency model or generative grammar that seeks to account for linguistic competence.

This research is in line with what was conveyed by Kadek (2005) where it is stated that when a child is able to use words fluently, then the child has high linguistic intelligence. According to Miksan (2016), people who have high linguistic intelligence have a sharp sensitivity to the sound or phonology of language which in this case linguistic intelligence consists of several components, including phonology, syntax, semantics and pragmatics. Someone who has a high linguistic intelligence is an excellent grammarian and is constantly looking for oral or written errors that sometimes occur in his own life or that of others.

The findings of this study also support past research conducted by Orhan and Hasan (2015) which found that multiple intelligences, especially linguistic intelligence, affect students' reading comprehension learning outcomes. Research from Aryani (2020) concluded in his research that the influence of linguistic intelligence and assignment was very effective in influencing students' English learning outcomes.

\subsection{The Interaction between the Two Learning Strategies and Linguistic Intelligence in Influencing Students' Learning Outcomes of Reading Comprehension of English Texts}

This study found an interaction between learning strategies and students' linguistic intelligence in influencing the learning outcomes of English texts reading comprehension. When viewed from the average learning outcomes of English, students who are taught with CSR learning strategies and have high linguistic intelligence have higher average English learning outcomes than students who are taught with DRTA learning strategies and high linguistic intelligence. In addition, the average English learning outcomes of students who are taught using the CSR strategy and have low linguistic intelligence are higher than the average English learning outcomes of students who are taught using the DRTA learning strategy and have low linguistic intelligence. This research is reinforced by previous research conducted by Syamsiani (2010) that learning strategies and linguistic intelligence have an influence on students' English learning outcomes at SMP Negeri 7 Binjai City. Research conducted by Hotlien (2016) also states that the interaction between learning strategies and linguistic intelligence will have a positive impact on students' English learning outcomes. This is because in the experimental class, students who have high linguistic intelligence tend to show enthusiasm and activeness when participating in learning activities, ask questions more often if they have any difficulty, and are able to solve problems given by the teacher.

\section{Research Limitations}

In this study, researchers faced several limitations that affected the conditions of the research conducted, including the following. 
1. Research was conducted online due to the COVID-19 pandemic, so there are limitations in terms of observation during the learning process.

2. Since the data on students' reading comprehension skills in English texts were obtained using multiple choice tests conducted online, the drawback that might arise is that students may only guess the answers.

\section{CONCLUSION AND SUGGESTION}

\section{Conclusion}

There is an effect of Collaborative Strategic Reading (CSR) and Directed, Reading, Thinking, Activity (DRTA) learning strategies and linguistic intelligence on reading comprehension of English texts for high school students in Medan.

\section{Suggestion}

It is recommended for schools to train teachers to get used to applying both learning strategies effectively in the classroom. In addition, improvement efforts for students who have low linguistic intelligence are also needed so that they can catch up with other students who have higher intelligence. Meanwhile, the motivation to study harder should be given on students who have high linguistic intelligence to make them achieve better reading comprehension ability of English texts.

\section{REFERENCES}

[1] M. O. Panjaitan, "Analisis Standar Isi Bahasa Inggris SMP dan SMA," Journal of Education and Culture., vol. 19, no. 1, p. 140, 2013.

[2] Ministry of Education and Culture, Minister of Education and Culture Regulation Number 21 of 2016 concerning Content Standards for Primary and Secondary Education. Indonesia, 2016.

[3] UNDP, "Human Development Indices and Indicators 2018 Statistical Update," 2018.

[4] F. Karabuga and E. S. Kaya, "Collaborative Strategic Reading Practice with Adult EFL Learners: A Collaborative and Reflective Approach to Reading," Procedia - Soc. Behav. Sci., vol. 106, pp. 621-630, 2013.

[5] I. F. Rahman, "the Implementation of Collaborative Strategy Reading (Csr) and Its Effects on Students' Reading Comprehension," ETERNAL (English, Teaching, Learn. Res. Journal), vol. 1, no. 1, pp. 39-56, 2016.

[6] C. D. Bremer and S. Vaughn, Collaborative Strategic Reading (CSR): Improving Secondary Students' Reading Comprehension Skills. Minneapolis: National Center in Secondary Education and Transition, 2012.

[7] J. K. Klingner, S. Vaughn, A. Boardman, and E. Swanson, "Now We Get It! Boosting
Comprehension with Collaborative Strategic Reading," Jossey-Bass, An Impr. Wiley, 2012.

[8] Dimyati and Mudjiono, Belajar dan Pembelajaran. Jakarta: PT. Rineka Cipta, 2006.

[9] T. Armstrong, 7 Kind Of Smart (Menemukan dan Meningkatkan Kecerdasan Anda berdasarkan Teori Multiple Intelegence). Jakarta: Gramedia Pustaka Utama, 2002.

[10] S. Tisnasari, "Kemampuan berbahasa sebagai konstruksi kecerdasan linguistik," Indonesian language and literature education., vol. 1, no. 2, pp. 143-149, 2014.

[11] K. Suarca, S. Soetjiningsih, and I. E. Ardjana, "Kecerdasan Majemuk pada Anak," Sari Pediatr., vol. 7, no. 2, p. 85, 2016.

[12] O. Iyitoglu and H. Aydin, "The relationship between multiple intelligence profiles and reading strategy use of successful English as a foreign language (EFL) readers," South African J. Educ., vol. 35 , no. 2,2015 . 